\title{
A bibliometric analysis of drinking water research in Africa
}

\author{
Enos W Wambu' and Yuh-Shan $\mathrm{Ho}^{2 *}$ \\ 'Department of Chemistry and Biochemistry, School of Science, University of Eldoret, P.O. Box 1125-30100, Eldoret, Kenya \\ ${ }^{2}$ Trend Research Centre, Asia University, No. 500, Lioufeng Road, Wufeng, Taichung County 41354, Taiwan
}

\begin{abstract}
A total of 1917 publications of drinking water research in Africa from 1991 to 2013 were identified from the data hosted in online version of SCI-Expanded, Thomson Reuters Web of Science, for bibliometric analysis. The analysis included publication output, distribution of keywords, journals and subject areas, and performances of countries, institutions, and authors. Citation trends and highly-cited publications are also reported. We found that the publication output of related documents increased over the entire period of study. The results showed that 'water', 'drinking water', and 'oxidative stress' were the most frequent terms in publication titles, authors' keywords and KeyWords Plus. The top three subject areas were 'water resources', 'environmental science', and 'environmental and occupational public health'. The ten most productive institutions were located in South Africa and Egypt, and the University of Pretoria was the overall most productive institution. Thus, a quarter of all of the articles published were from South Africa. It was found that articles became increasingly collaborative with greater numbers of authors, page counts and bibliographies. More than half of the internationally collaborative articles were co-authored with researchers from Europe. French and US institutions contributed to the highest number of collaborative articles.
\end{abstract}

Keywords: Africa, bibliometric review, drinking water, publications, research collaborations, water research

\section{INTRODUCTION}

At the moment the priority research areas in Africa are concerned with easement of disease burden, mitigating water scarcity and enhancing of food security (Pouris and Ho, 2014). In particular, drinking water research continues to attract intense interest from African researchers (Dagdeviren and Robertson, 2011). This has lead to a surge in publication output in this area, especially in recent years. This is because it is generally believed that affordable access to quality drinking water could both mitigate food shortage and help control the disease burden among communities (Hunter et al., 2010).

African research output in drinking water is, therefore, diverse, ranging from such aspects as hydrogeochemistry (Ghiglieri et al., 2012), availability assessments (Reimann et al., 2003), quality assessments (Campbell et al., 2003), and treatment (Mameri et al., 1998) to policy and management issues (Van der Zaag, 2005). To facilitate progress in water research in Africa, there is a need to consolidate the divergent knowledge base so as to focus Africa's research efforts in these disciplines.

Attempts towards this desired data integration include several systematic reviews by African research institutions (Kusangaya et al., 2014; Weinzierl and Schilling, 2013). While, systematic literature reviews are used in interrogating research status and often unravel useful details that could direct research and policy issues in the subsequent periods, such reviews address only a limited scope of data and are unhelpful in consolidating divergent data in open research fields like drinking water, and even more so if the field of study is multidisciplinary with authorship that traverses socio-political and academic borders.

It is found that in such cases bibliometric reviews provide more elaborate analyses (Li et al., 2011). The latter studies are based on quantitative statistical examination of publication

\footnotetext{
* To whom all correspondence should be addressed.

๔ +886423323456 ext. 1797; e-mail: ysho@asia.edu.tw

Received 17 April 2015; accepted in revised form 6 September 2016
}

trends, anchored on word-clusters and the distribution of terms in article titles, author keywords, and KeyWords Plus, among other indicators (Fu et al., 2013b; Khan and Ho, 2011). The criteria for bibliometric assessment is, thus, founded on examination of trends in research parameters, which adduce data used to assemble information that would characterize the evolutionary structure of research in a particular field of study (Feller and Bernoux, 2008). The analyses are geared towards exposing knowledge gaps and revealing emphases that would drive successive research in the study field (Nachega et al., 2012).

In view of the divergent geophysical characteristics of Africa, bibliometric studies that would address regional disparities in primary research areas are desired for focusing research efforts in Africa toward specific socio-economic challenges that face African communities (Chuang et al., 2011). This would provide an all-inclusive view of available data and inform tailored interventions. To date, only a few bibliometric studies have been conducted to appraise research work in the African context (Chuang et al., 2011; Pouris and Ho, 2014).

The current work was designed to screen drinking water research in Africa during the years spanning 1991 to 2013. The bibliometric research data were based on Science Citation Index Expanded (SCI-Expanded) in the Web of Science Core Collection. Trends in research productivity, author contributions and international collaboration were analysed. It was anticipated that the results would provide insight into the existing research trends and help researchers to discern the direction of science in drinking water research in Africa. It is hoped this will in turn help researchers to identify and engage knowledge gaps towards informed interventions into the problems that face the African continent.

\section{METHODS}

The data were drawn from the online version of SCI-Expanded, in Thomson Reuters Web of Science (updated on 30 July 2014). Algeria, Angola, Benin, Botswana, 'Burkina Faso', Burundi, 
Cameroon, Cape Verde, 'Cent Afr Empire', Chad, Comoros, Congo, 'Congo Peopl Rep', 'Congo Republic', 'Cote Ivoire,' 'Ivory Coast', Djibouti, 'Afars\&Issas', Egypt, 'Equat Guinea', Eritrea, Ethiopia, Gabon, Gambia, Ghana, Guinea, 'Guinea Bissau', Kenya, Lesotho, Liberia, Libya, Madagascar, 'MalagassyRepubl', Malawi, Mali, Mauritania, Mauritius, Morocco, Mozambique, Namibia, Niger, Nigeria, Rwanda, 'Sao Tome \&Prin', Senegal, Seychelles, 'Sierra Leone', Somalia, 'South Africa, 'South Sudan', Sudan, Swaziland, Tanzania, Togo, Tunisia, Uganda, Zambia, Zimbabwe, 'Dem Rep Congo, 'Western Sahara, and 'Spanish Sahara' were searched in terms of country. The terms 'drinking water', 'drinking waters', 'drinkable water,' 'drinkable waters', and 'drinking waterborne' (Fu et al., 2013b) were then searched in terms of topic (including 4 parts: title, abstract, authors' keywords, and KeyWords Plus) within the publication years ranging from 1991 to 2013. Articles originating from England, Scotland, Northern Ireland, and Wales were reclassified as being from the United Kingdom (UK).

The reported impact factor $\left(I F_{2013}\right)$ for journals were obtained from the Thomson Reuters Web of Science Journal Citation Reports of 2013. Classification of publications into articles, proceedings papers, reviews, meeting abstracts, notes, letters, editorial materials, corrections, and book chapters, were obtained using a search for document types. Contributions from institutions and countries were identified by occurrence of at least one author in the publications. Collaboration types were determined from the addresses of authors. Articles were classified based on the country and institution of origin as: 'single country articles', if the authors were from the same country; 'single institution articles', if the authors were from the same institution; 'internationally collaborative articles', if the articles were co-authored by researchers from multiple countries; 'inter-institutionally collaborative articles', if authors were from different institutions; 'first-author article', if the first author was from the country or institution for analysis; and, 'corresponding-author article', if the corresponding-author was from the country or institution for analysis. The total of number of citations of an article from its date of publication up to the end of the year 2013, was recorded as $T C_{2013}$. Articles with $T C_{2013}>60$ were selected as top-cited articles in drinking water research in Africa during this period. The citation frequencies, from publication up to the end of 2013, for each of the top-cited articles was then collected and analysed.

\section{RESULTS and DISCUSSION}

All published articles in drinking water research in Africa during the years 1991 to 2013 were analysed. The analysed parameters included: document type; publication language; volume and characteristics of publication output; subject categories; publication output by journals; performance of countries and research institutions; and trends in research collaborations. Citation patterns and distribution of title words, authors' keywords, and KeyWords Plus in different periods were also analysed.

\section{Main document type}

A total of 1719 documents were found within 9 document types indexed in the Thomson Reuters Web of Science. The most common document type was the research article (95\% of the 1719 documents), followed by proceedings papers (8.3\%), review papers $(3.2 \%)$, meeting abstracts $(0.70 \%)$, notes $(0.47 \%)$, letters $(0.47 \%)$, editorial materials $(0.12 \%)$, a correction, and a book chapter. The patterns in distribution of the document types were comparable to those reported in literature (Chuang et al., 2011). However, there were no bibliographical items, bibliographies, database reviews, research discussions, software reviews and reprints (as found in studies by Fu et al., 2013a; Tan et al., 2013) found in this study.

Citation data for different document types were analysed (Table 1). The total citation, $T C_{2013}$, for each document type was consistent with the total publication output $(T P)$ within the document types. This shows that higher publication output of a particular document type led to higher visibility and likelihood of citation within that document type. It was not surprising that reviews had higher citations per paper $(C P P)$ than articles because review papers cover a wider perspective of a research topic and present information to readers in a more integrated manner, which help readers to get a broader perspective of the subject matter compared to other primary document types. For this reason, reviews receive more citations than articles (Guimaraes and Carlini, 2004). It was, however, unusual that conference proceedings in the current analyses had higher $C P P$ than the articles. This indicates that drinking water research in Africa is still developing as researchers in mature research fields generally consult articles from reputable sources known for their high standards and rigorous peer-review. However, only the 1633 original research articles found in the current work were further examined as articles represented the majority of the peerreviewed documents in this field.

\section{Publication output and language}

Trends in distribution of research articles by year of publication were analysed (Fig. 1). The annual output of research articles increased from about 20 articles in the early 1990s to 71 articles in the year 2004. Publication output decreased to 54 articles in 2007 before again increasing to 194 articles by the year 2013 . The observed expansion in the research output reflected increased use of information technologies (Samuels et al., 1991) such as computers, the Internet (Blau et al., 2003) and mobile phones (Ailamaki et al., 2003), which enhanced data handling and transmission and access to scientific information during this period. The period under study also coincided with the time of rapid expansion in higher education in Africa leading to increased research output from the continent (Varghee, 2004).

The graph of 'number of articles' versus 'time in years' depicted in Fig. 1 is convex, which affirms that drinking water research in Africa is a developing study field. Similar plots normally assume a characteristic sigmoid shape for maturing study fields (Yu et al., 2012).

All in all, English was the language of choice for communicating scientific data, having been used to publish 1582 or 97\% of the 1633 research articles., followed by French (2.9\%), German $(0.12 \%)$ and Spanish $(0.061 \%)$. Scientific language use reflected historical ties between Africa and Western Europe, which are traceable to the $19^{\text {th }}$ century 'European scramble for Africa' (Griffiths, 1986). The publication languages found in the current study were, therefore, fewer than is normally the case in similar analyses (Fu et al., 2013a; Mao et al., 2010).

\section{Article characteristics}

As depicted in Table 2, drinking water research in Africa became increasingly collaborative over the period studied. The mean number of authors per article increased from 2.7 to 4.8 and mean paper length rose from 6.3 to 10 pages between the early $1990 \mathrm{~s}$ 


\begin{tabular}{|l|c|c|c|c|}
\hline \multicolumn{5}{|c|}{ TABLE 1 } \\
\begin{tabular}{|} 
Distribution of water research by document types of publi- \\
cation output in Africa between $\mathbf{1 9 9 1}$ and 2013
\end{tabular} \\
\hline \multicolumn{1}{|c|}{ Document type } & TP & \% & TC2013 & CPP \\
\hline Article & 1633 & 95 & 12968 & 7.9 \\
\hline Proceedings paper & 142 & 8.3 & 1166 & 8.2 \\
\hline Review & 55 & 3.2 & 839 & 15 \\
\hline Meeting abstract & 12 & 0.70 & 2 & 0.17 \\
\hline Note & 8 & 0.47 & 63 & 7.9 \\
\hline Letter & 8 & 0.47 & 57 & 7.1 \\
\hline Editorial material & 2 & 0.12 & 10 & 5.0 \\
\hline Correction & 1 & 0.058 & 0 & 0 \\
\hline Book chapter & 1 & 0.058 & 0 & 0 \\
\hline
\end{tabular}

TP: number of articles; $T C_{2013}$ : number of citations since publication to the end of 2013; CPP: citations per publication.

and 2013. The number of bibliographic sources per articles also increased from 13-22 citations, which was typical of research articles in the early 1990s, to $40-45$ citations per article after the year 2010

\section{Research focuses of drinking water research in Africa}

Statistical analysis of the frequency of key terms in article titles, authors' keywords, and KeyWords Plus provides details of research progress and indicates the direction of science in a research field. Distribution of title words, authors' keywords, and KeyWords Plus in different periods can be used to determine research focus (Li et al., 2009) and word clusters have been applied to characterize articles in the subsequent years (Mao et al., 2010).

A total of 115 title words appeared in at least 20 research articles in drinking water research in Africa during the study period. The top 10 most frequent title words were: 'water' (631; $39 \%$ of 1,633 articles), 'drinking' (238; $15 \%)$, 'rats' (142; 8.7\%), 'south' (141; 8.6), 'Africa' (124; 7.6\%), 'effect' (117; 7.2\%), 'treatment' (111; 6.8\%), 'rural' (95; 5.8\%), and 'ground water' (92; $5.6 \%)$. The analysis of authors' keywords revealed 199 keywords that appeared in at least 5 articles. The top 10 most frequent terms in authors' keywords were: 'drinking water' (123; 9.2\%), 'water quality' ( $71 ; 5.3 \%)$, 'water' $(68 ; 5.1 \%)$, 'groundwater' ( 51 ; $3.8 \%)$, 'oxidative stress' $(44 ; 3.8 \%)$, 'heavy metals' $(38 ; 2.8 \%)$, 'rat' $(35 ; 2.6 \%)$, 'rats' $(34 ; 2.5 \%)$, 'fluoride' $(31 ; 2.3 \%)$, and 'selenium' $(27 ; 2.0 \%)$. Using KeyWords Plus, 133 terms appeared in at least 11 articles. As for the authors' keywords, the most frequent term was 'drinking water' (361 articles; $26 \%$ of all articles) followed by 'lipid-peroxidation' (72; 5.3\%), 'toxicity' (66; 4.8\%), 'water' (66; $4.8 \%)$, 'quality' ( $62 ; 4.5 \%)$, 'removal' (51; $3.7 \%)$, 'diarrhea' (50; $3.7 \%)$, 'oxidative stress' $(47 ; 3.4 \%)$, 'exposure' (46; $3.4 \%)$, 'contamination' (45; 3.3\%), and 'adsorption' (45; 3.3\%).

Accordingly, the most frequent KeyWords Plus terms were more varied than the top title words but less diverse than the top authors' keywords. The term 'water' appeared in the top 10 category across title words, authors' keywords and KeyWords Plus. Two terms, 'drinking water' and 'rats', were found among the top 10 for title words and authors' keywords. Concurrent appearance of the terms 'South' $(141 ; 8.6 \%)$ and 'Africa' $(124 ; 7.6 \%)$ in title category alludes to the name 'South Africa', indicating the national origin of the research work. This underscored the central role played by South African research institutions in water research in Africa during this period. The term 'oxidative stress', which relates to the effect of reactive nitrogen oxides to biological systems (Betteridge, 2000), appeared in the top 10 most used

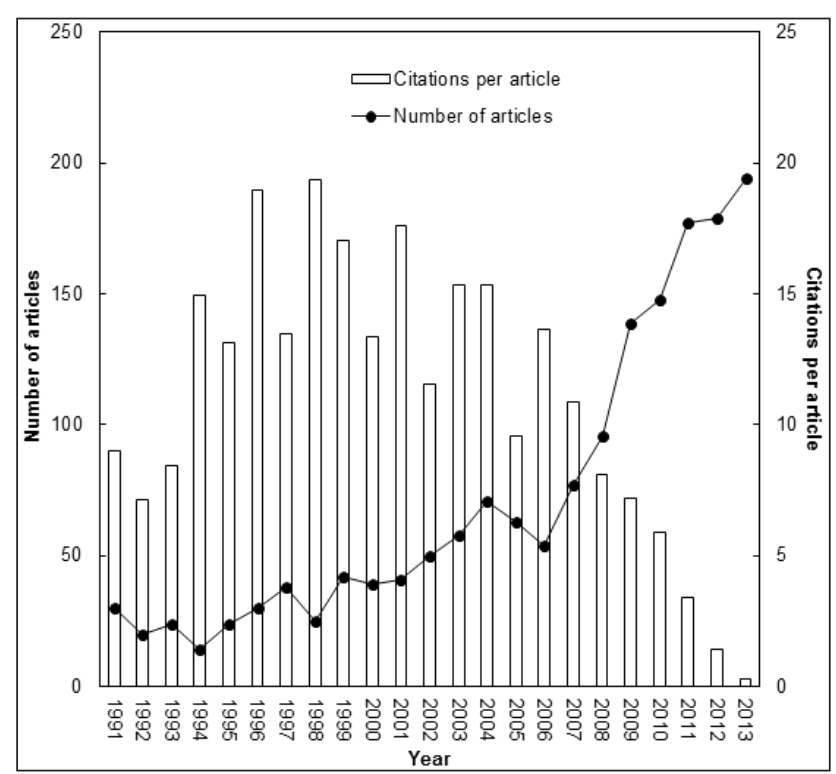

Figure 1

Number of articles and citations per article by year

terms across authors' keywords and KeyWords Plus. This suggests a significant interface between environmental toxicology, ecology and drinking water research in Africa during this period.

\section{Subject categories and journals of publication}

As depicted in Table 3, at least 28 journals from 15 different publishers published 10 or more articles on drinking water research in Africa during the reference period. The top 4 journal publishers were Springer, Pergamon-Elsevier Limited, Elsevier $\mathrm{BV}$ and IWA Publishing. The prevailing journal impact factors $\left(r^{2}=0.0052\right)$ and 5-year-cumulative journal impact factors $\left(r^{2}=0.0065\right)$ did not appear to determine the choice of journals for publishing drinking water research in Africa in the current study period. Nineteen subject areas contributed to at least 40 articles. The top subject areas were 'water resources' (445; 27\%)', environmental science' $(293 ; 24 \%)$, 'environmental and occupational public health' (197; 12\%), 'toxicology' (134; 8.2\%), 'environmental engineering' (126; 7.7\%), 'chemical engineering' (122; $7.5 \%)$, 'microbiology' (104; 6.4\%), 'biotechnology and applied microbiology' (73; $4.5 \%)$ ', tropical medicine' $(66 ; 4.1 \%)$, 'pharmacology and pharmacy' $(58 ; 3.6 \%)$, 'biochemistry and molecular biology' (57; 3.5\%), 'meteorology and atmospheric sciences' (57; $3.5 \%)$, 'dairy and animal science agriculture' $(54 ; 3.3 \%)$, 'veterinary sciences' ( $54 ; 3.3 \%)$, 'civil engineering' ( $47 ; 2.9 \%)$, 'infectious diseases' $(47 ; 2.9 \%)$, 'analytical chemistry' ( $46 ; 2.6 \%)$, and 'food science' $(32 ; 2.1 \%)$. More than half of the research was conducted in the areas of 'water resources' (27\%) and 'environmental science' (24\%). The rest of the research fell within subject areas of 'environmental sciences \& ecology' (16\%), 'water resources' (14\%), 'engineering' (12\%) and 'environmental \& occupational public health' $(7.7 \%)$. This was consistent with recent findings by Pouris and Ho (2014), which showed that 'environmental science', 'water resources', and 'public health' were still the key research areas in Africa.

\section{Performance of Africa research institutions and countries}

Research institutions from 43 Africa countries were involved in drinking water research during the 1991-2013 period. Forty-six of these institutions published at least 10 articles on drinking 
water research during this period. University of Pretoria (89 or $5.5 \%$ of the 1633 articles) was the most prolific institution overall, followed by University of Johannesburg $(41 ; 2.5 \%)$; Tshwane University of Technology (37; 2.3\%); Cairo University (36; $2.2 \%)$; Council for Scientific and Industrial Research (CSIR) (34; $2.1 \%)$; National Research Centre (33; 2.0\%); University of Alexandria (31; $1.9 \%)$; University of Ibadan $(31 ; 1.9 \%)$; University of the Witwatersrand (30;1.8\%); Addis Ababa University (28; $1.7 \%$ ); and University of KwaZulu-Natal (28; 1.7\%). The list of the 46 most productive institutions in drinking water research in Africa was, therefore, dominated by institutions from South Africa (13;28.3\%), Egypt (10;21.7\%), Tunisia (7; 15.2\%), and Nigeria $(6 ; 13.0 \%)$. Ten countries, including Botswana, Ethiopia, Ghana, Kenya, Malawi, Morocco, Sudan, Tanzania, Uganda, and Zimbabwe, were each represented by one institution among these elite research institutions.

The 21 most productive African countries in drinking water research during this period are listed in Table 4, with information about total articles, independent articles, collaborative articles, first author articles, corresponding-author articles, and single-author articles produced. As expected, a large proportion of water research in Africa during the 1991-2013 period was published by institutions from South Africa (402; $25 \%$ of all articles), followed by those from Egypt (270; 17\%), Nigeria (190; $12 \%)$ and Tunisia (158; 10\%). South Africa and Egypt were the top 2 African countries by total number of publications, singlecountry publications, internationally collaborative publications, first author publications, corresponding-author publications and single-author publications. Furthermore, the ranking of the top 4 African countries remained unchanged for $T P R, I P R, F P R$, and $R P R$. Morocco, Algeria and Kenya were the only countries outside the top 4 countries by TPR to break into the top 5 categories based on $I P R, C P R, F P R$, and $R P R$ groups.

These results mirrored the findings of similar analyses by Pouris and Ho (2014), in which South Africa, with 29474 or $26 \%$ of 111877 articles, was ranked the most collaborative African country, ahead of Egypt (24,126; 22\%), Tunisia (11 504; $10 \%)$, Nigeria ( $9664 ; 8.6 \%)$, Algeria $(7,391 ; 6.6 \%)$, Morocco $(6,153 ; 5.5 \%)$, and Kenya $(4,480 ; 4.0 \%)$. This indicates that drinking water research can be used to estimate more general research trends of a heterogeneous scientific community.

The current results were, however, at variance with those of earlier studies on 'public health research in Africa' (Chuang et al., 2011) and 'epidemiology and public health training and research in the WHO African region' (Nachega, 2012). The extent of inconsistency between the current findings and those of the two sets of data measures the degree of disconnect between drinking water research and public health-related research. In one of the cited works (Chuang et al., 2011), the merit of African countries in 'public-health research' was in the order: South Africa, (222; 20\% of 1086 articles), Kenya (93; 8.6\%), Egypt (82; 7.6\%), Nigeria (82; 7.6\%), and Tanzania (78; $7.1 \%)$. Similarly, an 'analysis of epidemiology and public health training and research' (Nachega et al., 2012), gave a ranking of: South Africa (1 978; $22.4 \%$ of 8835 articles), Kenya (851, $9.6 \%)$, Nigeria (758, 8.6\%), Tanzania $(549,6.2 \%)$, and Uganda $(428,4.8 \%)$

Given that the sub-Saharan states of East Africa feature strongly among the top countries in health-related research but not as strongly in the current analysis of drinking water research, this indicates that inter-regional differences in research emphasis control the research involvement of African researchers. Sub-Saharan states such as Kenya, Uganda, and Tanzania are more inclined towards health-related research due to a need

\begin{tabular}{|c|c|c|c|c|c|c|c|c|}
\hline \multicolumn{9}{|c|}{$\begin{array}{c}\text { TABLE } 2 \\
\text { Characteristics of drinking water scientific articles from } \\
\text { Africa between } 1991 \text { and } 2013\end{array}$} \\
\hline Year & TP & AU & $\begin{array}{c}\text { AU/ } \\
\text { TP }\end{array}$ & NR & \begin{tabular}{|c} 
NR/ \\
TP
\end{tabular} & PG & $\begin{array}{c}\text { PG/ } \\
\text { TP }\end{array}$ & $C P(\%)$ \\
\hline 1991 & 30 & 96 & 3.2 & 530 & 18 & 238 & 7.9 & $5(17)$ \\
\hline 1992 & 20 & 53 & 2.7 & 312 & 16 & 141 & 7.1 & $5(25)$ \\
\hline 1993 & 24 & 81 & 3.4 & 304 & 13 & 192 & 8.0 & $7(29)$ \\
\hline 1994 & 14 & 51 & 3.6 & 312 & 22 & 88 & 6.3 & $6(43)$ \\
\hline 1995 & 24 & 74 & 3.1 & 421 & 18 & 168 & 7.0 & $11(46)$ \\
\hline 1996 & 30 & 100 & 3.3 & 736 & 25 & 224 & 7.5 & $13(43)$ \\
\hline 1997 & 38 & 168 & 4.4 & 830 & 22 & 244 & 6.4 & $16(42)$ \\
\hline 1998 & 25 & 92 & 3.7 & 569 & 23 & 185 & 7.4 & $10(40)$ \\
\hline 1999 & 42 & 160 & 3.8 & 1017 & 24 & 294 & 7.0 & $20(48)$ \\
\hline 2000 & 39 & 156 & 4.0 & 944 & 24 & 316 & 8.1 & $18(46)$ \\
\hline 2001 & 41 & 143 & 3.5 & 886 & 22 & 323 & 7.9 & $16(39)$ \\
\hline 2002 & 50 & 208 & 4.2 & 1260 & 25 & 427 & 8.5 & $25(50)$ \\
\hline 2003 & 58 & 204 & 3.5 & 1652 & 28 & 464 & 8.0 & $27(47)$ \\
\hline 2004 & 71 & 256 & 3.6 & 1709 & 24 & 544 & 7.7 & $18(25)$ \\
\hline 2005 & 63 & 258 & 4.1 & 1999 & 32 & 544 & 8.6 & $20(32)$ \\
\hline 2006 & 54 & 211 & 3.9 & 1899 & 35 & 501 & 9.3 & $25(46)$ \\
\hline 2007 & 77 & 307 & 4.0 & 2277 & 30 & 676 & 8.8 & $32(42)$ \\
\hline 2008 & 96 & 381 & 4.0 & 3017 & 31 & 825 & 8.6 & $42(44)$ \\
\hline 2009 & 139 & 534 & 3.8 & 4550 & 33 & 1105 & 7.9 & $66(47)$ \\
\hline 2010 & 148 & 676 & 4.6 & 5852 & 40 & 1323 & 8.9 & $66(45)$ \\
\hline 2011 & 177 & 782 & 4.4 & 7236 & 41 & 1609 & 9.1 & $79(45)$ \\
\hline 2012 & 179 & 819 & 4.6 & 7339 & 41 & 1744 & 9.7 & $82(46)$ \\
\hline 2013 & 194 & 929 & 4.8 & 8790 & 45 & 1972 & 10 & $113(58)$ \\
\hline Total & 1633 & \begin{tabular}{|l|}
6739 \\
\end{tabular} & & 54441 & & 14147 & & \\
\hline Average & & & 3.8 & & 27.5 & & 8.1 & \\
\hline
\end{tabular}

TP: number of articles; AU: number of authors; NR: number of cited references; PG: number of pages; $C P$ : number of internationally collaborative articles; \%: percentage of internationally collaborative articles in each year

\begin{tabular}{|c|c|c|}
\hline \multicolumn{3}{|c|}{$\begin{array}{l}\text { TABLE } 3 \\
\text { Top } 10 \text { journals in drinking water research during the period } \\
1991-2013\end{array}$} \\
\hline Journal & TP & $\%$ \\
\hline Water SA & 96 & 5.9 \\
\hline Desalination & 58 & 3.6 \\
\hline Physics and Chemistry of the Earth & 45 & 2.8 \\
\hline Water Science and Technology & 42 & 2.6 \\
\hline Environmental Monitoring and Assessment & 35 & 2.1 \\
\hline Water Research & 25 & 1.5 \\
\hline Desalination and Water Treatment & 24 & 1.5 \\
\hline American Journal of Tropical Medicine and Hygiene & 22 & 1.3 \\
\hline African Journal of Microbiology Research & 22 & 1.3 \\
\hline Journal of Water and Health & 21 & 1.3 \\
\hline
\end{tabular}

TP: number of articles

to control tropical illnesses such as malaria (Lopez et al., 2006), and a myriad of waterborne illnesses (Harris et al., 2013). On the other hand, water scarcity was the primary concern of the research communities of the arid Northern Region, comprising the states of Egypt, Tunisia, Morocco, Libya and Algeria (Droogers et al., 2012).

Accordingly, North Africa, with a combined total of 598 or $37 \%$ of all the articles published in drinking water research during the current period of study, was the most prolific region, followed by West Africa (374; 23\%), East Africa (147; 9.0\%), Southern Africa (106; 6.0\%) when excluding South Africa, Horn of Africa $(75 ; 5.0 \%)$, and Central Africa $(4 ;<1.0 \%)$. It was noted 
TABLE 4

Top 21 African countries with more than 10 articles

\begin{tabular}{|c|c|c|c|c|c|c|c|}
\hline Country & TP & TPR (\%) & IPR (\%) & CPR (\%) & FPR (\%) & RPR (\%) & SPR (\%) \\
\hline South Africa & 402 & $1(25)$ & $1(31)$ & $1(16)$ & $1(21)$ & $1(21)$ & $2(21)$ \\
\hline Egypt & 270 & $2(17)$ & $2(18)$ & $2(15)$ & $2(12)$ & $2(12)$ & $1(30)$ \\
\hline Nigeria & 190 & $3(12)$ & $3(16)$ & $6(6.1)$ & $3(10)$ & $3(10)$ & $3(19)$ \\
\hline Tunisia & 158 & $4(10)$ & $4(10)$ & $3(9.4)$ & $4(8.5)$ & $4(8.5)$ & N/A \\
\hline Morocco & 94 & $5(5.8)$ & $6(4.2)$ & $4(7.8)$ & $5(4.0)$ & $5(4.0)$ & $9(1.6)$ \\
\hline Algeria & 76 & $6(4.7)$ & $5(4.4)$ & $7(5.0)$ & $6(3.7)$ & $6(3.7)$ & $4(7.3)$ \\
\hline Kenya & 74 & $7(4.5)$ & $9(2.1)$ & $5(7.6)$ & $9(1.8)$ & $9(1.7)$ & $5(3.2)$ \\
\hline Ghana & 57 & $8(3.5)$ & $7(3.0)$ & $9(4.2)$ & $7(2.1)$ & $7(2.1)$ & $5(3.2)$ \\
\hline Ethiopia & 54 & $9(3.3)$ & $8(2.3)$ & $8(4.6)$ & $8(2.0)$ & $8(2.0)$ & $9(1.6)$ \\
\hline Cameroon & 37 & $10(2.3)$ & $12(0.88)$ & $10(4.0)$ & $10(1.0)$ & $11(0.93)$ & N/A \\
\hline Tanzania & 37 & $10(2.3)$ & $11(1.0)$ & $11(3.9)$ & $10(1.0)$ & $10(1.0)$ & $5(3.2)$ \\
\hline Uganda & 30 & $12(1.8)$ & $17(0.55)$ & $12(3.5)$ & $13(0.67)$ & $13(0.68)$ & N/A \\
\hline Malawi & 28 & $13(1.7)$ & $15(0.66)$ & $13(3.0)$ & $13(0.67)$ & $13(0.68)$ & $9(1.6)$ \\
\hline Senegal & 26 & $14(1.6)$ & $17(0.55)$ & $14(2.9)$ & $13(0.67)$ & $15(0.62)$ & $13(0.81)$ \\
\hline Zimbabwe & 23 & $15(1.4)$ & $10(1.3)$ & $17(1.5)$ & $12(0.92)$ & $11(0.93)$ & $8(2.4)$ \\
\hline Sudan & 18 & $16(1.1)$ & $13(0.77)$ & $17(1.5)$ & $17(0.49)$ & $17(0.5)$ & $13(0.81)$ \\
\hline Botswana & 17 & $17(1.0)$ & $20(0.33)$ & $16(1.9)$ & $21(0.24)$ & $21(0.25)$ & N/A \\
\hline Cote Ivoire & 15 & $18(0.92)$ & $13(0.77)$ & $20(1.1)$ & $16(0.61)$ & $15(0.62)$ & N/A \\
\hline Zambia & 15 & $18(0.92)$ & N/A & $15(2.1)$ & $30(0.061)$ & $29(0.062)$ & $13(0.81)$ \\
\hline Burkina Faso & 12 & $20(0.73)$ & $23(0.11)$ & $17(1.5)$ & $20(0.31)$ & $20(0.31)$ & N/A \\
\hline Libya & 12 & $20(0.73)$ & $15(0.66)$ & $21(0.83)$ & $18(0.43)$ & $18(0.44)$ & $9(1.6)$ \\
\hline
\end{tabular}

TP: total articles; TPR (\%): rank and the percentage of total articles; IPR (\%): rank and the percentage of independent articles; CPR (\%): rank and the percentage of international collaborative articles; FPR (\%): rank and the percentage of first author articles; RPP (\%): rank and the percentage of the corresponding-authored articles; SPR (\%): rank and the percentage of single-author articles; N/A: not available.

that only 4 articles, from Chad and Congo Republic, were published from the entire equatorial region of Central Africa.

Besides the overarching regional imbalance in water research, availability of research capital including research technologies and related structures controlled inter-state disparities in drinking water research involvement by African researchers. Consequently, South Africa, Egypt and Nigeria (Chuang et al., 2011; Nachega et al., 2012; Pouris and Ho, 2014), which are among the countries with some of the most established research structures in Africa, dominate research output across all study fields.

\section{Research collaborations}

Collaborations among researchers, research institutions and countries play a pivotal role in contemporary science. To evaluate exchange of scientific information between Africa and the rest of the world, research collaborations between African scientists and research institutions from outside of Africa were analysed. The top 10 most collaborative institutions were ranked by total number of publications (TP), including correspondingauthor articles and first-author articles. A total of 799 or $48.9 \%$ of all drinking water research articles were published by African research institutions in collaboration with institutions from outside Africa. Over $26 \%$ of these articles were attributed to the 27 most collaborative institutions from outside Africa with at least 5 co-authored research articles with African researchers in this period. The top 5 institutes in this category were Centre for Disease Control \& Prevention (30; 1.8\%); King Saud University (11;0.67\%); University of Montpellier (11; 0.67\%); King Abdulaziz University (11;0.67\%); and University of Bergen (10; $0.61 \%)$. The list of the top 27 collaborative institutions from outside Africa was dominated by institutions from the UK (7; $26 \%)$, France (5; 19\%), USA ( $4 ; 15 \%)$, Saudi Arabia (4; 15\%); Germany (2; 7.4\%), and Norway (2; 7.4\%). Ireland, Japan and Spain were each represented by one institution among these 27 elite institutions.

In all, 54 countries had collaborations with Africa in drinking water research. The most collaborative countries from outside Africa, in terms of accrued collaborative articles were France (140 articles; $18 \%$ of 799 articles), USA (134; 17\%), UK (74; 9.3\%), Saudi Arabia (50; 6.3\%), Germany (43; 5.4\%), and Japan (40, 5.0\%). The largest proportion of the collaborative research articles was co-authored with institutions from Europe (444 articles; 56\% of 799 articles), North America (161;20\%), Far East (93; 12\%), Middle East (73; 9.1\%), Australia (18; 2.3\%), and South America (10;1.3\%). The distribution of collaborations 
in the current analysis was similar to that reported in literature (Li et al., 2008).

The collaborative agencies that retained first-authorship of collaborative articles also retained corresponding-authorship $\left(r^{2}>0.988\right)$. German (92\%), Saudi (72\%), and Norwegian (71\%) institutions retained highest proportion of first- and corresponding-authorship in their collaborative articles with African institutes, whereas French (32.7\%) and Spanish (38.7\%) agencies had the lowest proportion of first-author and corresponding-author articles with African researchers.

\section{Article visibility and citation trends}

To assess the visibility of research articles, the number of times an article was cited from publication till the end of $2013\left(T C_{2013}\right)$ was used as an indicator (Chuang et al., 2007). Reader preferences and scientific impact of published work were studied by analysing the 19 most cited publications in drinking water research in Africa from 1991 to 2013. The list of the most cited articles $\left(T C_{2013}>60\right)$ is given in Table 5. With the single exception of one review paper, the entire list of top cited works comprised of research articles. The main subject areas covered by the 19 most cited articles were: 'water defluoridation' ( 4 articles) and 'water fluoride' ( 1 article), which were cited 572 times; followed by 'in vivo animal tests' ( 4 articles), cited 372 times; 'solar water purification technology' ( 3 articles) with 343 citations; 'general water purification technologies' ( 2 articles) with 142 citations; and 'heavy metal water pollution' ( 1 article) with 89 citations.

The high readership of articles on the subject of water fluoride was expected when it is considered that large portions of Africa, including regions along the Great Rift Valley from Sudan through Southern Sudan, Djibouti, Eritrea, Ethiopia, Kenya, Uganda, Tanzania, Malawi, down to South Africa; West African states of Niger, Nigeria, and Senegal (Ayoob and Gupta, 2006); and Northern Africa states of Egypt (El-Sadaawy and El-Said, 2014), Algeria (Achour and Youcef, 2009), and Tunisia (Hamdi and Srasra, 2009) are well known high-fluoride areas of the world. Therefore, in view of the high toxicities and the risk of high-fluoride exposure for the communities in the affected areas, the fate of fluoride in groundwater resources remains a major public health concern (Wambu et al., 2014).

Figure 2 shows that the visibility of the articles increased rapidly after the year 2000 . Whereas the apparent reeason for this upsurge was not immediately clear, the current study period coincided with a time of rejuvenation and expansion in higher education and the academic sector in Africa (Varghee, 2004). The period also corresponds to the inception of the computer era and expanded use by researchers in Africa of electronic data retrieval systems and the Internet to access research databases (Ailamaki et al., 2003; Blau et al., 2003). An analysis of citation trends of drinking water research articles among the top African countries is depicted in Fig. 3. Visibility of articles reached its maximum within 2-3 years of publication and decreased thereafter to near-zero in 17-22 years, as previously reported by Chuang et al. (2007) and Zhang (2012). However, the actual duration of optimum scientific visibility of articles varied from country to country. Articles from Tunisia had the highest mean visibility of 2.0 citations per article. They were followed by articles of Egyptian ( $\sim 1.5$ citations), South African ( 1.4 citations), and Nigerian ( $\sim 1.0$ citations) origin. As can be seen from Fig. 4, internationally collaborative articles had the highest visibility and scientific impact followed by inter-institutional collaborative articles, single-country articles and single-author articles, respectively.

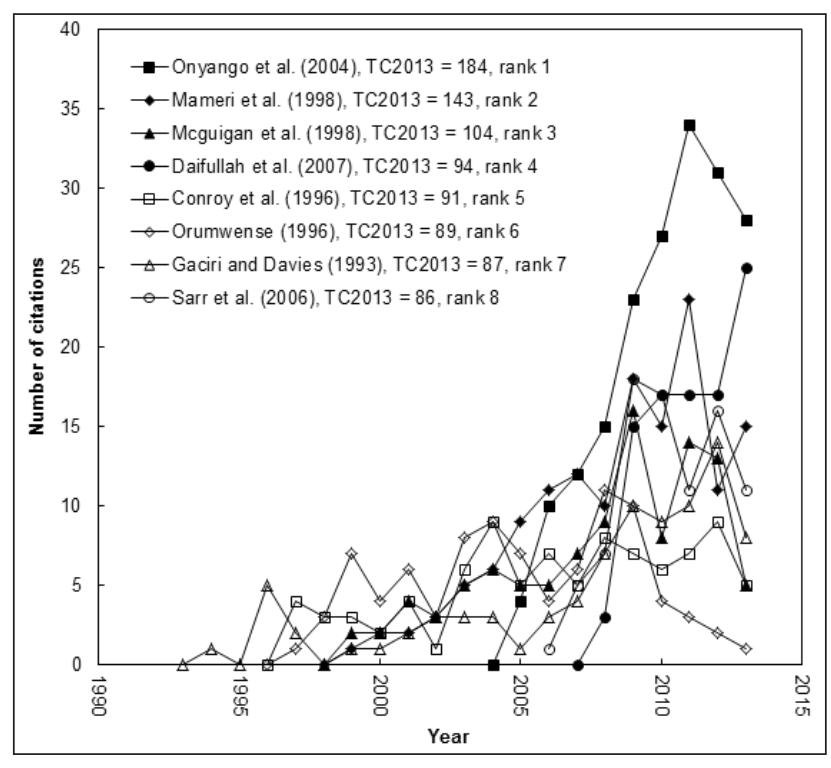

Figure 2

Number of citations per article by year for the top seven most cited articles in drinking water research in Africa from 1991 to 2013

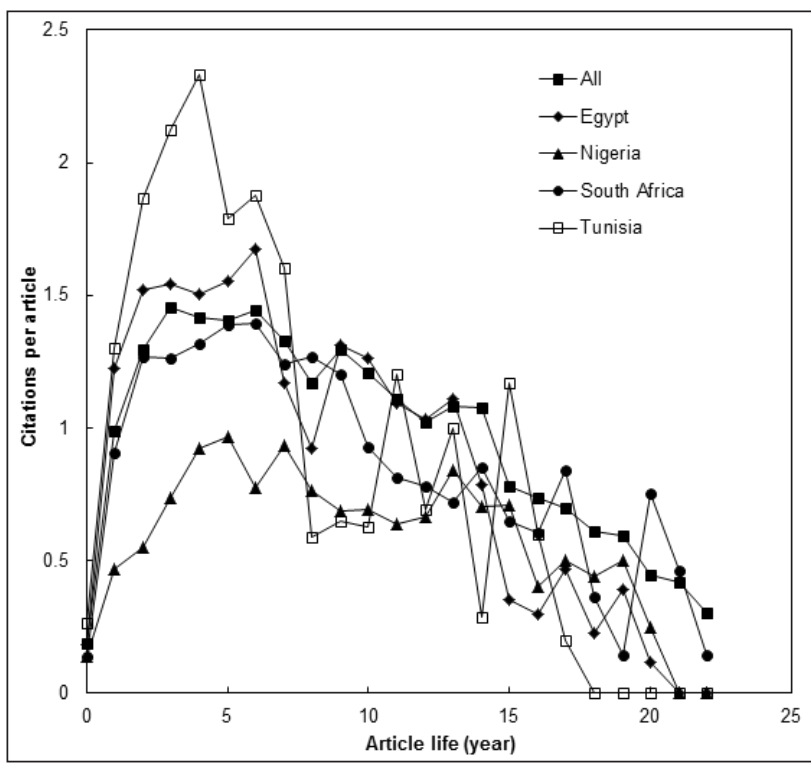

Figure 3

Visibility of research articles by country of origin

\section{CONCLUSIONS}

An overview of drinking water research in Africa during the 1991-2013 period has been presented with respect to annual publication outputs, Web of Science subject categories, research areas, journals, institutions, countries, and trends in collaboration, research emphases and tendencies. The publication output in this field increased at exponential rates over the entire study period. It has been adduced therefore that drinking water research in Africa is a developing field of study. The key subject categories of study were: 'water resources', 'environmental science,' and 'environmental and occupational health public'. Environmental toxicology and ecology, therefore, significantly controlled Africa's water research during this time. Research output by African countries was, however, controlled by availability of research capital and regional differences in environmental 


\begin{tabular}{|c|c|c|}
\hline \multicolumn{3}{|c|}{$\begin{array}{c}\text { TABLE } 5 \\
\text { Top } 19 \text { articles with } \text { TC2013> } 60\end{array}$} \\
\hline $\begin{array}{l}\text { Rank } \\
\text { (TC2013) }\end{array}$ & Article title & Reference \\
\hline $1(184)$ & $\begin{array}{l}\text { Adsorption equilibrium modeling and solution chemistry dependence of fluoride removal from water by } \\
\text { trivalent-cation-exchanged zeolite F-9 }\end{array}$ & Onyango et al. (2004) \\
\hline $2(143)$ & $\begin{array}{l}\text { Defluoridation of septentrional Sahara water of north Africa by electrocoagulation process using bipolar } \\
\text { aluminium electrodes }\end{array}$ & Mameri et al. (1998) \\
\hline $3(104)$ & $\begin{array}{l}\text { Solar disinfection of drinking water contained in transparent plastic bottles: characterizing the bacterial } \\
\text { inactivation process }\end{array}$ & McGuigan et al. (1998) \\
\hline $4(94)$ & $\begin{array}{l}\text { Adsorption of fluoride in aqueous solutions using KMnO4-modified activated carbon derived from steam } \\
\text { pyrolysis of rice straw }\end{array}$ & Daifullah et al. (2007) \\
\hline $5(91)$ & Solar disinfection of drinking water and diarrhoea in Maasai children: A controlled field trial & Conroy et al. (1996) \\
\hline $6(89)$ & Removal of lead from water by adsorption on a kaolinitic clay & Orumwense (1996) \\
\hline $7(87)$ & The occurrence and geochemistry of fluoride in some natural-waters of Kenya & Gaciri and Davies (1993) \\
\hline $8(86)$ & $\begin{array}{l}\text { Red wine polyphenols prevent angiotensin II-induced hypertension and endothelial dysfunction in rats: } \\
\text { Role of NADPH oxidase }\end{array}$ & Sarr et al. (2006) \\
\hline $9(83)$ & Inactivation of fecal bacteria in drinking water by solar heating & Joyce et al. (1996) \\
\hline $10(77)$ & Review of electro-assisted methods for water purification & Grimm et al. (1998) \\
\hline $10(77)$ & $\begin{array}{l}\text { Effect of ascorbic acid and Vitamin E supplementation on semen quality and biochemical parameters of } \\
\text { male rabbits }\end{array}$ & Yousef et al. (2003) \\
\hline $12(76)$ & $\begin{array}{l}\text { Thymoquinone attenuates ifosfamide-induced Fanconi syndrome in rats and enhances its antitumor activ- } \\
\text { ity in mice }\end{array}$ & Badary (1999) \\
\hline $13(72)$ & $\begin{array}{l}\text { Antioxidant effect of vitamin } \mathrm{E} \text { and selenium on lipid peroxidation, enzyme activities and biochemical } \\
\text { parameters in rats exposed to aluminium }\end{array}$ & El-Demerdash (2004) \\
\hline $14(69)$ & Outbreak of acute hepatitis-e virus-infection among military personnel in northern Ethiopia & Tsega et al. (1991) \\
\hline $15(66)$ & Drinking water quality in the Ethiopian section of the East African Rift Valley I - data and health aspects & Reimann et al. (2003) \\
\hline $16(65)$ & Solar disinfection of water reduces diarrheal disease: an update & Roberts et al. (2001) \\
\hline $16(65)$ & Keeping clean water clean in a Malawi refugee camp: a randomized intervention trial & Conroy et al. (1999) \\
\hline $18(64)$ & Study of a new technique for fluoride removal from water & Loucini et al. (1997) \\
\hline $19(62)$ & Inhibition of benzo (a)pyrene-induced forestomach carcinogenesis in mice by thymoquinone & Badary et al. (1991) \\
\hline
\end{tabular}

$T C_{2013}$ : number of citations from Web of Science Core Collection of an article from its publication up to the end of year 2013

factors. The overarching research challenges were disease burden in the sub-Saharan region and water shortage in the arid north. About $25 \%$ of all publications in drinking water research were published by South African institutions and the distribution of drinking water research by region for the rest of Africa followed the order: North Africa $>$ West Africa $>$ East Africa $>$ Southern Africa $>$ Horn of Africa $>$ Central Africa. Collaborative research became increasingly attractive and about half of all articles were co-authored by African researchers and collaborative institutions from Europe, North America, and the Far East. The most collaborative countries were France and USA. The highest visibility and scientific impact of publications were associated with review articles and internationally collaborative articles.

\section{RECOMMENDATIONS}

Drinking water research in Africa bore the marks of a developing research field and there is still a paucity of data in many aspects of this field. The African states and international community must make deliberate efforts to promote research in this field and bridge the gaps to meet the technological demand for research data in this area.

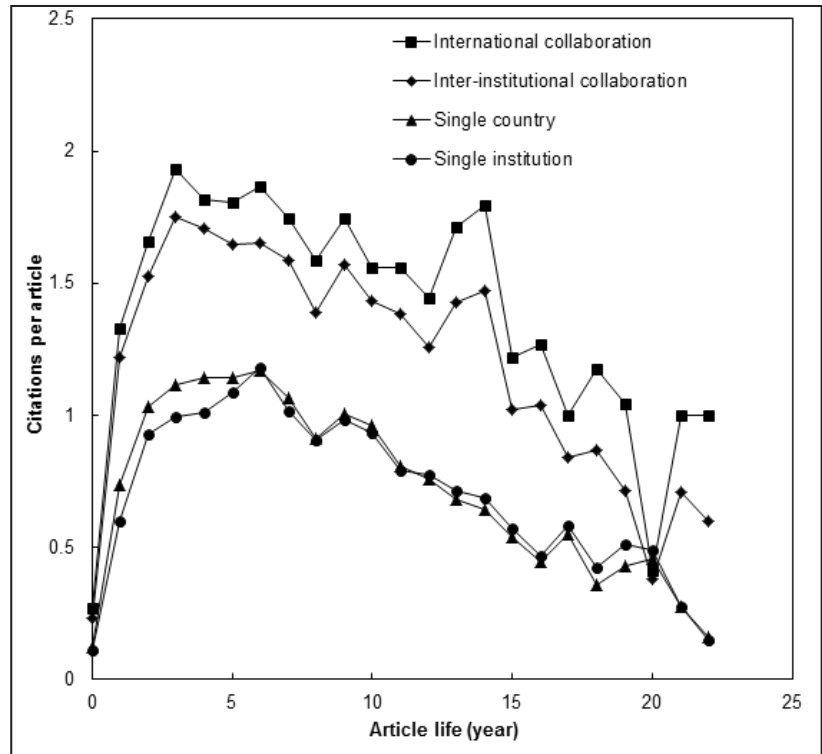

Figure 4

Effect of collaborations on article visibility 
An interesting topic for future research would be to break down the analysis of the data by African regional blocks in order to examine the type of water research that dominates in the different regions of the continent.

Current results showed that environmental safety is increasingly becoming a subject of concern to Africa. Deliberate efforts must be made by all stakeholders and players in the relevant sectors to safeguard African water resources, especially the crossborder water resources, to curb any further degradation.

\section{REFERENCES}

ACHOUR S and YOUCEF L (2009) Defluoridation of the Algerian north Sahara waters by adsorption onto local bentonites. Int. J. Envir. Stud. 66 151-165.

AILAMAKI A, FALOUTSOS C, FISCHBECK PS, SMALL MJ and VANBRIESEN J (2003) An environmental sensor network to determine drinking water quality and security. Sigmod Rec.32 47-52.

AYOOB S AND GUPTA K (2006) Fluoride in drinking water: A review on the status and stress effects. Crit. Rev. Environ. Sci. Technol.36 433-487.

BADARY OA (1999) Thymoquinone attenuates ifosfamide-induced Fanconi syndrome in rats and enhances its antitumor activity in mice. J. Ethnopharmacol. 67 135-142.

BADARY OA, AL-SHBANAH OA, NAGI MN, AL-RIKABI AC and ELMAZAR MMA (1991) Inhibition of benzo (a)pyrene-induced forestomach carcinogenesis in mice by thymoquinone. Eur. J. Cancer Prev. 8 435-440.

BETTERIDGE DJ (2000) What is oxidative stress. Metabolism 49 3-8.

BLAU JN, KELL CA and SPERLING JM (2003) Brief communication. Water-deprivation headache: a new headache with two variants. Headache 44 79-83.

CAMPBELL L, DIXON DG and HECKY RE (2003) A review of mercury in Lake Victoria, East Africa: implications for human and ecosystem health. J. Toxicol. Env. Health-Pt B-Crit. Rev. 6 325-356.

CHUANG KY, CHUANG YC, HO M and HO YS (2011) Bibliometric analysis of public health research in Africa: The overall trend and regional comparisons. S. Afr. J. Sci. 107 1-6.

CHUANG KY, HUANG YL and HO YS (2007) A bibliometric and citation analysis of stroke-related research in Taiwan. Scientometrics $\mathbf{7 2}$ 201-212.

CONROY RM, ELMORE-MEEGAN M, JOYCE T, MCGUIGAN KG and BARNES J (1996) Early reports Solar disinfection of drinking water and diarrhoea in Maasai children: a controlled field trial. Lancet 348 1695-1697.

CONROY RM, MEEGAN ME, JOYCE T, MCGUIGAN K and BARNES J (1999) Solar disinfection of water reduces diarrhoeal disease: an update. Arch. Dis. Child. 81 337-338.

DAGDEVIREN H and ROBERTSON SA (2011) Access to water in the slums of sub-Saharan Africa. Dev. Polic. Rev. 29 485-505.

DAIFULLAH AAM, YAKOUT SM and ELREEFY SA (2007) Adsorption of fluoride in aqueous solutions using KMnO4-modified activated carbon derived from steam pyrolysis of rice straw. J. Hazardous Mater. 147 633-643.

DROOGERS P, IMMERZEEL WW, TERINK W, HOOGEVEEN J, BIERKENS MFP, VAN BEEK LPH and DEBELE B (2012) Water resources trends in Middle East and North Africa towards 2050. Hydrol. Earth Syst. Sci. 16 3101-3114.

EL-DEMERDASH FM (2004) Antioxidant effect of vitamin E and selenium on lipid peroxidation, enzyme activities and biochemical parameters in rats exposed to aluminium. J. Trace Elem. Med. Biol. 18 113-121.

EL-SADAAWY MM and EL-SAID GF (2014) Assessment of fluoride in three selected polluted environments along the Egyptian Mediterranean Sea: Effects on local populations. Hum. Ecol. Risk Assess. 20 1643-1658.

FELLER C and BERNOUX M (2008) Historical advances in the study of global terrestrial soil organic carbon sequestration. Waste Manage. 28 734-740.
FU HZ, LONG X and HO YS (2013a) China's research in chemical engineering journals in Science Citation Index Expanded: a bibliometric analysis. Scientometrics 98 119-136.

FU HZ, WANG MH and HO YS (2013b) Mapping of drinking water research: A bibliometric analysis of research output during 19922011. Sci. Total Environ. 443 757-765.

GACIRI SJ and DAVIES TC (1993) The occurrence and geochemistry of fluoride in some natural waters of Kenya 143. J. Hydrol. 143 395-412.

GHIGLIERI G, PITTALIS D, CERRI G and OGGIANO G (2012) Hydrogeology and hydrogeochemistry of an alkaline volcanic area: the NE Mt. Meru slope (East African Rift - Northern Tanzania). Hydrol. Earth Syst. Sci. 16 529-541.

GRIFFITHS I (1986) The scramble for Africa: Inherited political boundaries. Geogr. J. 152 (2) 204-216.

GRIMM J, BESSARABOV D and SANDERSON R (1998) Review of electro-assisted methods for water purification. Desalination 115 285-294.

GUIMARAES JA and CARLINI CR (2004) Most cited papers in Toxicon. Toxicon 44 (4 345-359.

HAMDI N and SRASRA E (2009) Retention of fluoride from industrial acidic wastewater and $\mathrm{NaF}$ solution by three Tunisian clayey soils. Fluoride 42 39-45.

HARRIS AR, BOEHM AB and DAVIS J (2013) Mechanisms of postsupply contamination of drinking water in Bagamoyo, Tanzania. J. Water Health 11 543-554.

HUNTER PR, MACDONALD AM and CARTER RC (2010) Water supply and health. PLoS Med 7 (11) e1000361. doi:10.1371/journal. pmed.1000361.

KHAN MA and HO YS (2011) Arsenic in drinking water: A review on toxicological effects, mechanism of accumulation and remediation. Asian J. Chem. 23 1889-1901.

KUSANGAYA S, WARBURTON ML, ARCHER VAN GARDEREN E and JEWITT GPW (2014) Impacts of climate change on water resources in southern Africa: A review. Phys. Chem. Earth Parts $A / B / C$ 67-69 47-54

JOYCE TM, MCGUIGAN KG, CONROY RM and GUIGAN KGMC (1996) Inactivation of fecal bacteria in drinking water by solar heating. Appl. Environ. Microbiol. 62 399-402.

LI J, WANG MH and HO YS (2011) Trends in research on global climate change: A Science Citation Index Expanded-based analysis. Glob. Planet. Change 77 13-20.

LI LL, DING GH, FENG N, WANG MH and HO YS (2009) Global stem cell research trend: Bibliometric analysis as a tool for mapping of trends from 1991 to 2006. Scientometrics $8039-58$.

LI T, HO YS and LI CY (2008) Bibliometric analysis on global Parkinson's disease research trends during 1991-2006. Neurosci. Lett. 441 248-52.

LOPEZ AD, MATHERS CD, EZZATI M, JAMISON DT and MURRAY CJL (2006) Global and regional burden of disease and risk factors, 2001: systematic analysis of population health data. Lancet 367 1747-1757.

LOUCINI H, L; A, BELHOCINE D, GRIB H, DROUICHE M, PAUSS A and MAMERI N (1997) Study of a new technique for fluoride removal from water. Desalination 114 241-251.

MAMERI N, YEDDOU AR, LOUNICI H, BELHOCINE D, GRIB H and BARIOU B (1998) Defluoridation of septentrional Sahara water of North Africa by electrocoagulation process using bipolar aluminium electrodes. Water Res. 32 1604-1612.

MAO N, WANG MH and HO YS (2010) A bibliometric study of the trend in articles related to risk assessment published in Science Citation Index. Hum. Ecol. Risk Assess. 16 801-824.

NACHEGA JB, UTHMAN OA HO YS, LO M, ANUDE C, KAYEMBE P, WABWIRE-MANGEN F, GOMO E, SOW PS, OBIKE U, KUSIAKU T, MILLS EJ, MAYOSI BM and IJSSELMUIDEN C (2012) Current status and future prospects of epidemiology and public health training and research in the WHO African region. Inter. J.Epidemiol. 41 $1829-46$.

MCGUIGAN KG, JOYCE TM, CONROY RM, GILLESPIE JB and ELMORE-MEEGAN M (1998) Solar disinfection of drinking water contained in transparent plastic bottles: characterizing the bacterial inactivation process. J. Appl. Microbiol. 84 1138-1148. 
ONYANGO MS, KOJIMA Y, AOYI O, BERNARDO EC and MATSUDA H (2004) Adsorption equilibrium modeling and solution chemistry dependence of fluoride removal from water by trivalentcation-exchanged zeolite F-9. J. Colloid Interface Sci. 279 341-350.

ORUMWENSE FFO (1996) Removal of lead from water by adsorption on a kaolinitic clay. J. Chem. Technol. Biotechnol. 65 363-369.

POURIS A and HO YS (2014) Research emphasis and collaboration in Africa. Scientometrics 98 2169-2184.

REIMANN C, BJORVATN K, FRENGSTAD B, MELAKU Z, TEKLEHAIMANOT R and SIEWERS U (2003) Drinking water quality in the Ethiopian section of the East African Rift Valley I--data and health aspects. Sci. Total Environ. 311 65-80.

ROBERTS L, CHARTIER Y, CHARTIER O, MALENGA G, TOOLE M and RODKA H (2001) Keeping clean water clean in a Malawi refugee camp: a randomized intervention trial. Bull. World Health Organ. 79 280-287.

SAMUELS WB, TAYLOR PL, EVENHOUSE PB, BONDELID TR, EGGERS PC and HANSON SA (1991) The environmental display manager: A tool for water-quality data integration. Water Resour. Bull. 27 939-956.

SARR M, CHATAIGNEAU M, MARTINS S, SCHOTT C, EL BEDOUI J, OAK M-H, MULLER B, CHATAIGNEAU T and SCHINIKERTH VB (2006) Red wine polyphenols prevent angiotensin II-induced hypertension and endothelial dysfunction in rats: role of NADPH oxidase. Cardiovasc. Res. 71 794-802.

TAN J, FU HZ and HO YS (2013) A bibliometric analysis of research on proteomics in Science Citation Index Expanded. Scientometrics 98 1473-1490.

TSEGA E, KRAWCZYNSKI K, HANSSON BG, NORDENFELT E, NEGUSSE Y, ALEMU W and BAHRU Y (1991) Outbreak of acute hepatitis E virus infection among military personnel in northern Ethiopia. J. Med. Virol. 34 232-236.
VAN DER ZAAG P (2005) Integrated Water Resources Management: Relevant concept or irrelevant buzzword? A capacity building and research agenda for Southern Africa. Phys. Chem. Earth Parts A/B/C 30 867-871.

VARGHEE NV (2004) Private higher education in Africa, Revised version of the paper presented at the Policy Forum on Private Higher Education in Africa held on 2-3 November 2004 in Accra, Ghana. International Institute for Educational Planning (IIEP) in conjunction with Association for the Development of Education in Africa (ADEA) and Association of African Universities (AAU), UNESCO, Accra, Ghana. 1-30.

WAMBU EW, AGONG SG, ANYANGO B, AKUNO W and AKENGA T (2014) High fluoride water in Bondo-Rarieda area of Siaya County, Kenya: a hydro-geological implication on public health in the Lake Victoria Basin. BMC Public Health 14 462-470.

WEINZIERL T and SCHILLING J (2013) On demand, development and dependence: a review of current and future implications of socioeconomic changes for integrated water resource management in the Okavango Catchment of Southern Africa. Land 2 60-80.

YOUSEF MI, ABDALLAH GA and KAMEL KI (2003) Effect of ascorbic acid and Vitamin E supplementation on semen quality and biochemical parameters of male rabbits. Anim. Reprod. Sci. 76 99-111.

YU JJ, WANG MH, XU M and HO YS (2012) A bibliometric analysis of research papers published on photosynthesis: 1992-2009. Photosynthetica 50 5-14.

ZHANG J, WANG MH and HO YS (2012) Bibliometric analysis of aerosol research in meteorology and atmospheric sciences. Int. J. Environ. Pollut. 49 (1-2) 16-35. 